\title{
DIWANIYAH RIVER HYDROLOGY AND ITS IMPACT ON THE ADEQUACY OF IRRIGATION FOR AGRICULTURE
}

\author{
A.P. D. Jwan Sameen Ahmed \\ Ministry of Higher Education and Science Research \\ University of Baghdad, College of Education (Ibn-Rushd) \\ Department of Geography
}

DOI: $10.37648 / \mathrm{ij} r s s h . v 10 \mathrm{i} 01.055$

Received:19 $9^{\text {th }}$ November 2019; Accepted:-2 $2^{\text {nd }}$ January, 2020; Published: $29^{\text {th }}$ January, 2020

\begin{abstract}
The study of rivers is one of the important Hydrology studies that is increasingly important with the increase in population and the Diwaniyah river is one of the rivers that did not study hydrological study and is passing through a dry area where temperatures rise and the research dealt with the problem which is the effect of the Hydrology characteristics of the Diwaniyah River on the adequacy of irrigation for agriculture and there were Justifications for studying the increase of the problem due to the entry of the river in a dry area and one of the most important conclusions of the research is the fluctuation of rain and high humidity in the region for these years and the lowest water revenue by $(9,542,880)$ m3/year and the deficit during the dry season (-3470004) During the rainy season (342000,14) $m 3$.
\end{abstract}

\section{INTRODUCTION}

Water tables are one of the most important natural resources on which the localization and development of human civilization depends, and water remains the foundation of life, what The Almighty said in writing (and made water everything alive). The importance of water in desert and semi-desert areas is greatly increased, and its importance increases over time due to population growth and increased requirements for human development and food security, whose realization depends on the abundance of water for various activities such as agriculture and industry. That the hydrological study of water resources is one of the important studies focused on the international associations so came

\section{STUDY PROBLEM}

1- What is the impact of the hydrological characteristics of the Diwaniyah River on agricultural development
2- Is the net water supply in the Diwaniyah River sufficient and amounts to a water deficit.

\section{HYPOTHESIS}

1- The hydrology properties of the Diwaniyah River have important implications for agricultural development.

2- The net water in the Diwaniyah River is not constant, resulting in a water shortage in the study area.

\section{JUSTIFICATIONS FOR STUDY}

The rationale for the study is that water is necessary for a human being, there is no life without water.

1- The existence of the hydrological studies of the Diwaniyah River as hydrology.

2. The importance of the river increases due to its entry into a dry area and the role of water 
in the characteristics of the hydrological situation in various activities increases with an increase in population growth rates.

\section{STUDY LIMITS}

The Diwaniyah River is located in the province of Qadisiyah, which is located between the two viewing circles $\left(181^{\circ} 31\right)$ and $\left(242^{\circ} 32\right)$ to the north, two long lines (24 $24 \mathrm{~K} \mathrm{44}$ ) and (6 $4945^{\circ}$ east), while geographically located in the middle of the Central Euphrates region, surrounded by five provinces, bordered by the north, the province of Babylon, and From the west and north-west of Najaf governorate, to the south by Muthanna governorate, to the south-east by DhiQar province, and to the northeast by Wasit province, see map (1)

\section{B- Temporal boundaries:}

Climatic data: climatic data for a long climate cycle (31) years was adopted in the period (1986-2016) of the study area station (Diwaniyah station) and agricultural statements for selected years

\section{Diwaniyah River:}

At the area of Sadr al-Dagara, then passes through the center of the province and the district of Al-Sadir and the center of Hamza district and continues in its direction towards the south until it enters the territory of Muthanna province at Imam Hamza district alRumaita within the administrative borders of Muthanna province, see map (1), a dirt, unlined river controlled by two gates, and built a series of bridges because of its penetration of the city of Diwaniyah from about half, and it is the longest waterway severing through the province from the north to the south. It has a length of $126 \mathrm{~km}$, and its discharge capacity has reached 60 $\mathrm{m} 3 / \mathrm{th}$, which is an area estimated at 500,000 dunums, and from the table (1) It is clear that the rates of scoring in the Diwaniyah River vary according to the months of the year as well as vary from year to year, and the rate of discharge takes a rise in the months (June, July, August, September, October and November) and these months were recorded the highest discharge rates in 2014 ( 63.71, 69.54, 66.73 68.12, $77.37,83.14 \mathrm{~m} 3$, respectively, due to the high rates of scoring for the months mentioned due to the high temperatures that lead to the need for irrigation in these months, which requires greater water releases, and then decreases discharge in the remaining months (December, December, February and March Nissan and Mays) for the same year record $(66.42,51.33$, $43.17,54.38,50.22,48.51 \mathrm{~m} 3 /$ tha) respectivelyIn the study of the table (1) it is clear that the year 2015 recorded a significant decrease in discharge for the rest of the years (2012-2017) due to the lack of rainfall (rain and snow) which feeds the Euphrates River as well as increased water consumption, high temperatures and evaporation in the study area, as shown by the The same table that the discharge rates for 2017 were close to those of 2014 but were relatively lower than in October and November, with the highest rates $(75.61,80.35 \mathrm{~m} 3$ respectively). 
(1) Ali Abdul Zahra Kazem al-Waili, Surface Water Resources and Its Impact on Agriculture in Al-Qadisiyah Governorate, Professor's Journal, No. 51, Faculty of Education - Ibn Rushd, University of Baghdad, 2004, p. 530.

Map (1)

Extensions of the Diwaniyah River in Qadisiyah Province

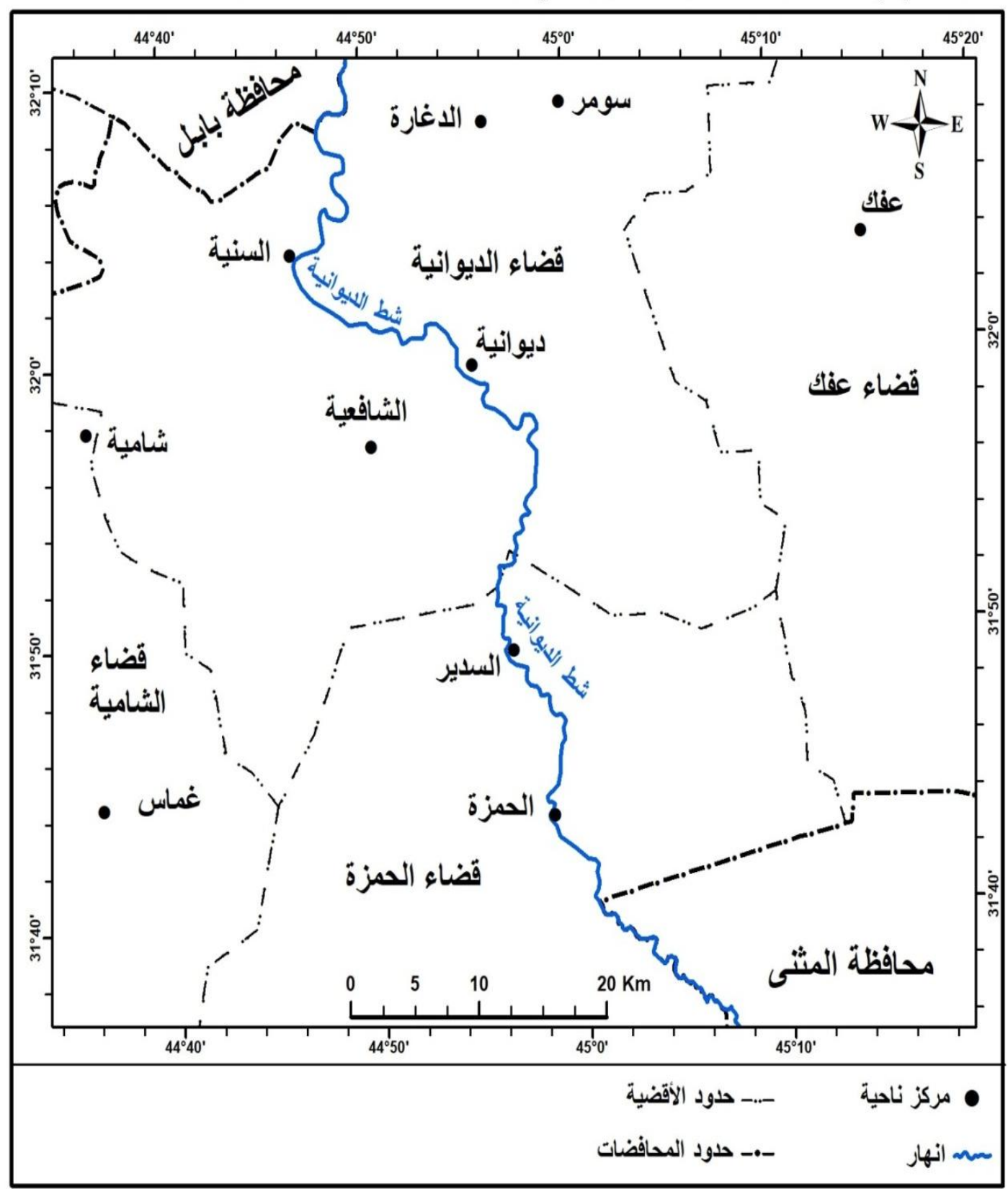

Source: Ministry of Water Resources, Diwaniyah Water Resources Directorate, Employment Division, Unpublished Data, 


\begin{tabular}{|c|c|c|c|c|c|c|c|c|c|c|c|c|c|c|c|c|c|c|c|}
\hline $\begin{array}{r}\text { Type } \\
\text { of } \\
\text { mont } \\
\text { h }\end{array}$ & $\begin{array}{r}\text { Discha } \\
\text { rge } \\
\text { Rate } \\
\text { Factor } \\
\text { Model } \\
207\end{array}$ & $\begin{array}{r}\text { Disch } \\
\text { arge } \\
\text { M3/T } \\
\text { HA } \\
2017\end{array}$ & $\begin{array}{r}\text { Type } \\
\text { of } \\
\text { mont } \\
\text { h }\end{array}$ & $\begin{array}{r}\text { Discha } \\
\text { rge } \\
\text { Rate } \\
\text { Factor } \\
\text { Model } \\
2016\end{array}$ & $\begin{array}{r}\text { Disch } \\
\text { arge } \\
\text { M3/T } \\
\text { HA } \\
2016\end{array}$ & $\begin{array}{r}\text { Type } \\
\text { of } \\
\text { mont } \\
\text { h }\end{array}$ & $\begin{array}{r}\text { Disch } \\
\text { arge } \\
\text { Rate } \\
\text { Factor } \\
\text { Mode } \\
12015\end{array}$ & $\begin{array}{r}\text { Discharg } \\
\text { e } \\
\text { M3/TH } \\
\text { A } 2015\end{array}$ & $\begin{array}{r}\text { Type } \\
\text { of } \\
\text { mont } \\
h\end{array}$ & $\begin{array}{r}\text { Dischar } \\
\text { ge rate } \\
\text { factor } \\
\text { model } \\
2014\end{array}$ & $\begin{array}{r}\text { Disch } \\
\text { arge } \\
\text { M3/T } \\
\text { HA } \\
2014\end{array}$ & $\begin{array}{r}\text { Type } \\
\text { of } \\
\text { mont } \\
\text { h }\end{array}$ & 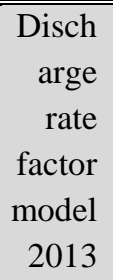 & $\begin{array}{r}\text { Disc } \\
\text { harge } \\
\text { M3/s } \\
2013\end{array}$ & $\begin{array}{r}\text { Type } \\
\text { of } \\
\text { mont } \\
h\end{array}$ & $\begin{array}{r}\text { Disch } \\
\text { arge } \\
\text { rate } \\
\text { factor } \\
\text { model } \\
2012\end{array}$ & $\begin{array}{r}\text { Discha } \\
\text { rge } \\
\text { M3/T } \\
\text { HA } \\
2012\end{array}$ & month & $\begin{array}{r}\text { Chap } \\
\text { ter }\end{array}$ \\
\hline Wet & 1.12 & 67.54 & Wet & 1.14 & 65.33 & $\begin{array}{r}\text { Mode } \\
\text { rate }\end{array}$ & 0.89 & 33.41 & Wet & 1.10 & 68.12 & Wet & 1.11 & 67.88 & wet & 1.12 & 66.51 & $\begin{array}{l}\text { Septe } \\
\text { mper }\end{array}$ & Fall \\
\hline Wet & 1.26 & 75.61 & Wet & 1.24 & 71.10 & Wet & 1.04 & 39.14 & Wet & 1.25 & 77.37 & Wet & 1.25 & 76.11 & Wet & 1.27 & 75.19 & $\begin{array}{r}\text { Octobe } \\
\mathbf{r}\end{array}$ & \\
\hline Wet & 1.33 & 80.35 & Wet & 1.29 & 74.22 & Wet & 1.15 & 43.26 & Wet & 1.34 & 83.14 & Wet & 1.35 & 82.15 & Wet & 1.37 & 81.10 & $\begin{array}{r}\text { novem } \\
\text { ber }\end{array}$ & \\
\hline Wet & 1.04 & 62.99 & Wet & 1.05 & 60.28 & Wet & 1.00 & 37.55 & Wet & 1.07 & 66.42 & Wet & 1.06 & 64.73 & Wet & 1.04 & 61.82 & $\begin{array}{r}\text { Decmb } \\
\text { er }\end{array}$ & $\begin{array}{r}\text { winte } \\
\mathbf{r}\end{array}$ \\
\hline $\begin{array}{l}\text { Mode } \\
\text { J rate }\end{array}$ & 0.83 & 49.86 & $\begin{array}{r}\text { Mode } \\
\text { rate }\end{array}$ & 0.83 & 47.54 & $\begin{array}{r}\text { Mode } \\
\text { rate }\end{array}$ & 0.88 & 31.32 & $\begin{array}{c}\text { Mod } \\
\text { erate }\end{array}$ & 0.82 & 51.33 & Dry & 0.01 & 50.27 & Dry & 0.68 & 49.11 & $\begin{array}{r}\text { Januar } \\
\mathbf{y}\end{array}$ & \\
\hline Dry & 0.67 & 40.65 & Dry & 0.66 & 38.13 & $\begin{array}{r}\text { Mode } \\
\text { rate }\end{array}$ & 0.81 & 30.42 & Dry & 0.01 & 43.17 & Dry & 0.68 & 41.48 & Dry & 0.68 & 40.21 & $\begin{array}{r}\text { Ferbru } \\
\text { ary }\end{array}$ & \\
\hline $\begin{array}{r}\text { Mode } \\
\text { rate }\end{array}$ & 0.87 & 52.50 & $\begin{array}{r}\text { Mode } \\
\text { rate }\end{array}$ & 0.90 & 51.49 & Wet & 1.04 & 39.14 & $\begin{array}{c}\text { Mod } \\
\text { erate }\end{array}$ & 0.87 & 54.38 & $\begin{array}{r}\text { Mode } \\
\text { rate }\end{array}$ & 0.87 & 53.23 & $\begin{array}{c}\text { Mod } \\
\text { erate }\end{array}$ & 0.86 & 51.13 & April & $\begin{array}{r}\text { Sprin } \\
\mathrm{g}\end{array}$ \\
\hline $\begin{array}{r}\text { Mode } \\
\text { rate }\end{array}$ & 0.80 & 48.41 & $\begin{array}{r}\text { Mode } \\
\text { rate }\end{array}$ & 0.84 & 48.21 & $\begin{array}{r}\text { Mode } \\
\text { rate }\end{array}$ & 0.94 & 35.37 & $\begin{array}{c}\text { Mod } \\
\text { erate }\end{array}$ & 0.81 & 50.22 & $\begin{array}{r}\text { Mode } \\
\text { rate }\end{array}$ & 0.81 & 49.20 & $\begin{array}{c}\text { Mod } \\
\text { erate }\end{array}$ & 0.80 & 47.22 & March & \\
\hline Dry & 0.67 & 45.49 & Dry & 0.75 & 43.25 & $\begin{array}{r}\text { Mode } \\
\text { rate }\end{array}$ & 0.97 & 36.28 & Dry & 0.78 & 48.51 & Wet & 0.67 & 46.51 & Dry & 0.76 & 45.10 & May & \\
\hline Wet & 1.01 & 60.70 & Wet & 1.02 & 58.66 & $\begin{array}{r}\text { Mode } \\
\text { rate }\end{array}$ & 0.92 & 34.61 & Wet & 1.02 & 63.71 & Wet & 1.02 & 62.19 & Wet & 1.00 & 59.15 & Jun e & $\begin{array}{l}\text { Sum } \\
\text { mer }\end{array}$ \\
\hline Wet & 1.14 & 68.78 & Wet & 1.14 & 65.67 & Wet & 1.18 & 44.12 & Wet & 1.12 & 69.54 & Wet & 1.12 & 68.11 & Wet & 1.14 & 67.24 & July & \\
\hline بWet & 1.06 & 64.12 & Wet & 1.09 & 62.34 & Wet & 1.16 & 43.52 & Wet & 1.07 & 66.73 & Wet & 1.08 & 65.48 & Wet & 1.07 & 63.28 & August & \\
\hline- & - & 60 & - & - & 57.18 & - & - & 37.35 & - & - & 61.88 & - & - & 60.61 & - & - & 58.92 & $\begin{array}{c}\text { Avera } \\
\text { ge }\end{array}$ & \\
\hline
\end{tabular}


Table (1) monthly and annual rate of discharge, and model of discharge rate factor $(*)$ in the Diwaniyah River for the duration (2012-2017)

Source: Researcher based on: Ministry of Water Resources, Directorate of Water Resources in Diwaniyah, GIS Division, Unpublished Data, 2018.

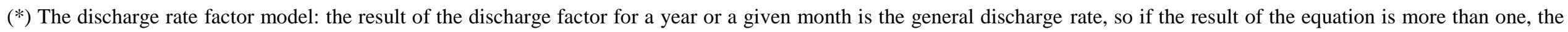

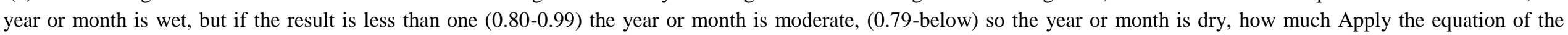

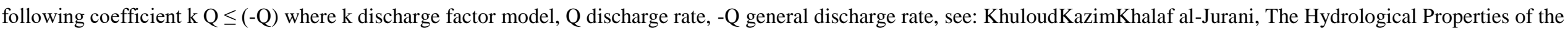
Tigris River in Maysan and Basra provinces, unpublished master's letter submitted to the Faculty of Education at Basra University, 2014 , p. 107.

Table (2)

Annual rates for the highest and lowest level (m) of the Diwaniyah River for the duration (2012-2017)

\begin{tabular}{|l|l|l||}
\hline Lowest level (m) & Highest level (M) & Year \\
\hline 1.44 & 2,86 & 2012 \\
\hline 1.56 & 2.96 & 2013 \\
\hline 1.62 & 2.98 & 2014 \\
\hline 1.19 & 2.11 & 2015 \\
\hline 1.48 & 2.53 & 2016 \\
\hline 1.75 & 2.88 & 2017 \\
\hline
\end{tabular}

Source: Ministry of Water Resources, Diwaniyah Water Resources Directorate, Employment Division, Unpublished Data, 2018.

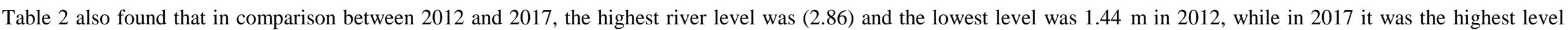

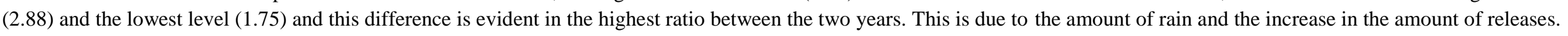


Branching streams from the right side of the Diwaniyah River

A- The modern shafi'a table: - which branchats at the kilometer (35.82), which is length (32.2) km and with a discharge rate of (9.5) $\mathrm{m} 3 /$ th see table (15) and shape (14), the area it narrates is (88931) without, which is a non-earthy table Padded controlled by three gates in the chest with four pumps, as the dimensions of this regulator is six meters wide and five meters high see picture (3), and branch the small excavator shatt from the modern shafi'i table at kilometer (8.2) and its length (12.5) km and its actual discharge capacity (1.7) $\mathrm{m} 3 /$ th.

B- The old Shafi'i aye table: it branches at the kilometer (35.82) from the right bank of the Diwaniyah Shatt alDiwaniyah and is $7.8 \mathrm{~km}$ long and has a drainage card of (0.4) $\mathrm{m} 3 /$ tha and narrates an area (4378) without it, controlled by a single gate, which is an unlined earthy table, see picture (4).

C- Um Abbasid table: The branch of this table is at the kilo (42.75) from the right bank of the Diwaniyah Shatt and has a length $(6.0) \mathrm{km}$, while its drainage capacity has reached (2.1) $\mathrm{m} 3 /$ tha and tells an area (5007) without, an unlined earthy table that controls the chest of one gate.

D - Ghanem Table: Branching from the right bank of the Diwaniyah River at 20.63 kilometers, with a length of (3.5) $\mathrm{km}$ at a discharge rate (1.3) $\mathrm{m} 3 / \mathrm{th}$ and controlled by two gates, which is a dirt table, and irrigates an area (2285) dunum

E- The Schedule of the Shatt Diwaniyah*: This table branched at the kilo (35.82), at the right of the Diwaniyah River with a relatively large length of $(27) \mathrm{km}$, and its discharge rate (41.8) $\mathrm{m} 3 /$ tha, controlled by two electric radial gates 4 x 5 meters, a earthy table looking at the image (5), tells an area (6241) dunum

Branching streams from the left side of the Diwaniyah River

A- The Nooria table: The Nooria table is branched from the modern shafi'i aye table at 12 kilometers, and is the easiest of the Diwaniyah River, with a length of (28) $\mathrm{km}$ and a discharge rate of $(1.5 \mathrm{~m} 3 / \mathrm{th})$, controlled by two gates and an area estimated at about (7214) dunums.

B- Sherifia Table: The left of the Diwaniyah River is branched at a kilo (0.34) km, with a discharge rate of (2.97) $\mathrm{m} 3 /$ tha, controlled by two gates and four American-type pumps with a capacity of $1 \mathrm{~m} 3 /$ th and fast (6.6) $\mathrm{rpm}$ and the lifting (8) meters, a padded table, looking at the image (6), and narrating an area estimated at about (3594) without 
As in map (2) and table (3)

Map (2) Diwaniyah River and streams branching from its right and left sides

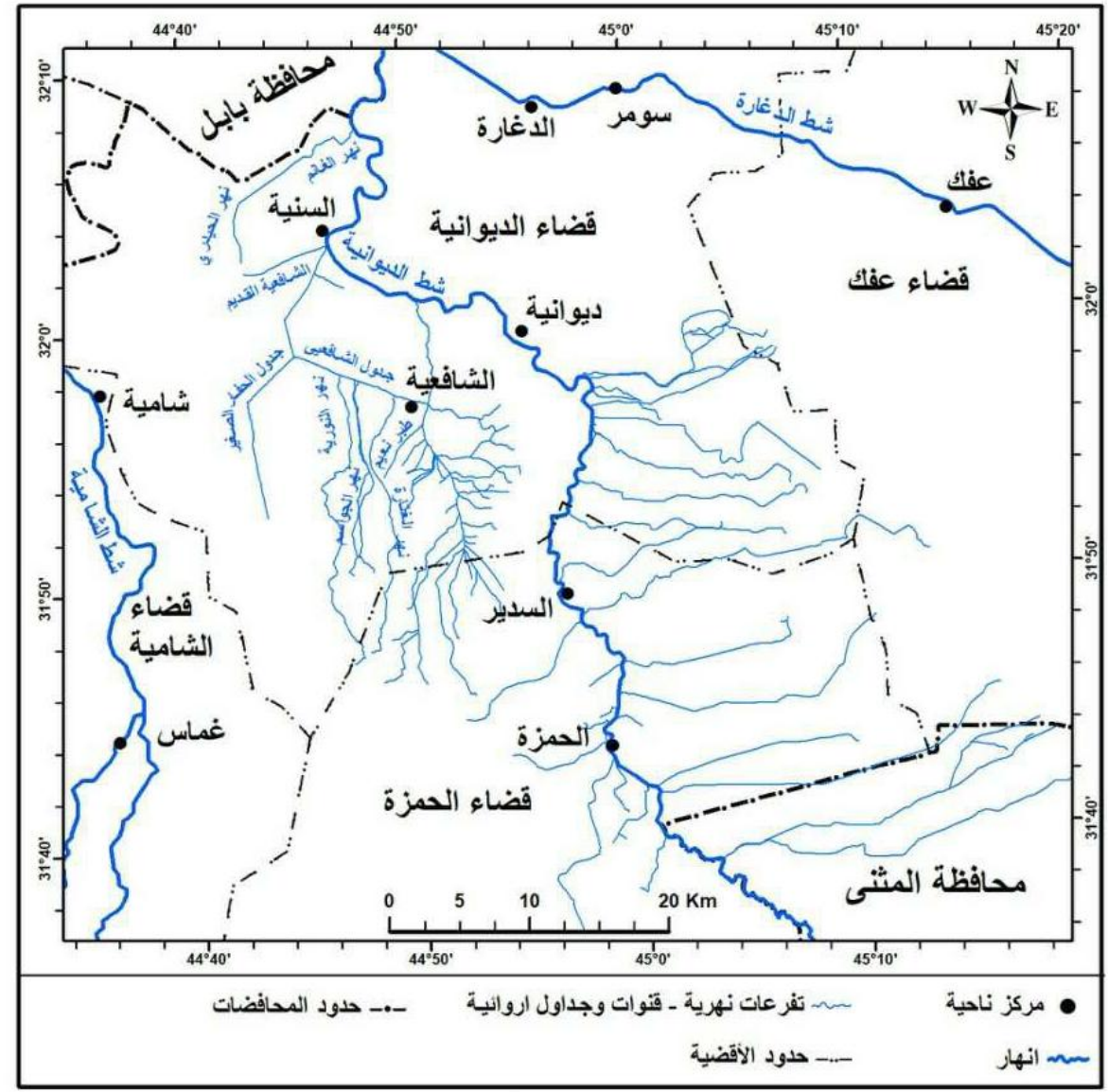

Source: Ministry of Water Resources, Diwaniyah Water Resources Directorate, Employment Division, Unpublished Data, 2018 
(IJRSSH) 2020, Vol. No. 10, Issue No. I, Jan-Mar

e-ISSN: 2249-4642, p-ISSN: 2454-4671

Table (3) Diwaniyah River and its branches

\begin{tabular}{|c|c|c|c|c|c|c|c|c|}
\hline Type $\begin{array}{r}\text { of } \\
\text { lining }\end{array}$ & Discharge M3/S & $\begin{array}{r}\text { Number } \begin{array}{r}\text { of } \\
\text { gates }\end{array} \\
\end{array}$ & $\begin{array}{r}\text { Length } \\
\text { KM }\end{array}$ & Fork & $\begin{array}{l}\text { The location } \\
\text { of the fork } \\
\text { sleeve }\end{array}$ & \multicolumn{2}{|c|}{$\begin{array}{r}\text { The name of the table or the river } \\
\text { or the beach }\end{array}$} & ت \\
\hline earthy & 60 & - & 126 & - & Shatt Al-Hillah & \multicolumn{2}{|c|}{ Diwaniyah River } & 1 \\
\hline earthy & 1.5 & 2 & 28 & left & 12 & Nuriya schedule & A & \\
\hline earthy & 9.5 & 3 & 32.2 & right & 35.82 & The modern $\begin{array}{r}\begin{array}{r}\text { Shafi'i } \\
\text { schedule }\end{array} \\
\end{array}$ & B & \\
\hline earthy & 0.4 & 1 & 7.8 & right & 35.82 & The old Shafi'i schedule & $\mathrm{C}$ & \\
\hline earthy & 2.1 & 1 & 6 & right & 42.75 & The schedule of Abbasid & $\mathrm{D}$ & \\
\hline padded & 2.9 & 2 & 15.6 & left & 0.34 & Sharifia schedule & $\mathrm{E}$ & \\
\hline earthy & 41.8 & 2 & 27 & Right & 35.82 & $\begin{array}{r}\text { Schedule of Shat Diwaniya } \\
\text { divert }\end{array}$ & $\mathrm{F}$ & \\
\hline earthy & 1.3 & 2 & 3.5 & right & 20.63 & Al-Ghanim schedule & G & \\
\hline
\end{tabular}

Source: Ministry of Water Resources, Diwaniyah Water Resources Directorate, GIS Division, Unpublished Data, 2018.

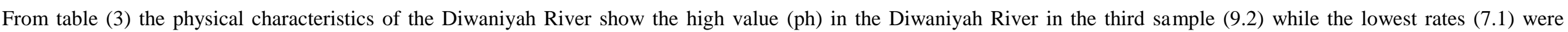

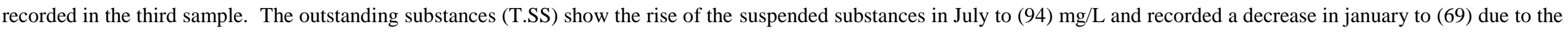

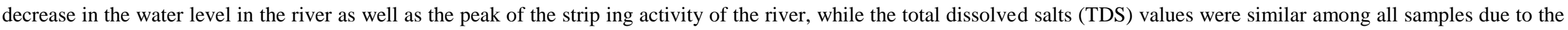
salt balance in the water of the main source. In other terms, the river continuously increases in certain amounts of water throughout the year. As in table (4) 
Table (4) Physical characteristics of the waters of the Diwaniyah River

\begin{tabular}{|c|c|c|c|c|c|c|c|c|c|c|c|}
\hline Temp. C & $\begin{array}{r}\text { Depth } \\
\text { (cm) }\end{array}$ & $\begin{array}{l}\text { Turbidity } \\
\left({ }^{*}\right)(\text { NTU })\end{array}$ & $\begin{array}{r}\text { E.C } \\
\text { ds } / m\end{array}$ & T.D.S mg/ I & T.S.S mg/I & PH & $\begin{array}{r}\text { Elements } \\
\text { العتاصر }\end{array}$ & & & & The data \\
\hline $\begin{array}{r}\text { Water } \\
\text { temperat } \\
\text { ure }^{\circ} \mathbf{m}\end{array}$ & $\begin{array}{l}\text { Water } \\
\text { depth and } \\
\text { light } \\
\text { transmitt } \\
\text { ance } \\
\quad \mathrm{cm}\end{array}$ & $\begin{array}{l}\text { Brownish } \\
\text { (Alkurah) }\end{array}$ & $\begin{array}{l}\text { Electrical } \\
\text { conductivi } \\
\text { ty } \\
\mathrm{Mm} / \mathrm{cm}\end{array}$ & 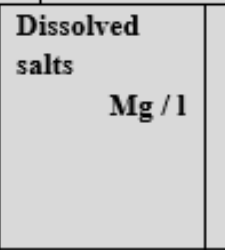 & $\begin{array}{r}\text { Suspended } \\
\text { matter }\end{array}$ & PH & the month & $\begin{array}{r}\text { Meridian } \\
\mathrm{s}\end{array}$ & Latitude & Location & the river \\
\hline 38 & 299 & 16.5 & 3.8 & 717 & 87 & 8.9 & July & $53^{\prime} 44^{\circ}$ & $0^{\circ} 32^{\circ}$ & Sample 1 & Diwaniyah \\
\hline 17 & 203 & 4.6 & 1.2 & 706.2 & 69 & 8.1 & As 2 & $53^{\prime} 44^{\circ}$ & $0^{\prime} 32^{\circ}$ & Sample 1-1 & River \\
\hline 37 & 223 & 18.7 & 4.7 & 777.8 & 98 & 8.8 & July & $56^{\prime} 44^{\circ}$ & $52^{\prime} 31^{\circ}$ & Sample 2 & \\
\hline 18 & 134 & 5.5 & 1.18 & 711.2 & 73 & 7.1 & As 2 & $56^{\prime} 44^{\circ}$ & $52^{\circ} 31^{\circ}$ & Sample 2-2 & \\
\hline 38 & 156 & 19.2 & 5.3 & 823.1 & 94 & 9.2 & July & $58^{\prime} 44^{\circ}$ & $44^{\prime} 31^{\circ}$ & Sample 3 & \\
\hline 17.5 & 105 & 6.7 & 1.2 & 805.3 & 77 & 8.3 & As 2 & $58^{\prime} 44^{\circ}$ & $44^{\prime} 31^{\circ}$ & Sample 3-3 & \\
\hline
\end{tabular}


Table (5) Table of chemical properties of diwaniyah river water

\begin{tabular}{|c|c|c|c|c|c|c|c|c|c|c|c|c|}
\hline & $\mathbf{N a}$ & $\mathbf{M g}$ & & Hco3 & No3 & So4 & & Eleme & \multicolumn{3}{|c|}{ The date } & \multirow[b]{2}{*}{ River } \\
\hline $\begin{array}{r}\text { Potassi } \\
\text { um }\end{array}$ & $\begin{array}{r}\text { Sodiu } \\
\mathbf{m}\end{array}$ & $\begin{array}{r}\text { magne } \\
\text { sium }\end{array}$ & $\begin{array}{r}\text { Calci } \\
\text { um }\end{array}$ & $\begin{array}{r}\text { Bicarbo } \\
\text { nate }\end{array}$ & $\begin{array}{l}\text { Nitr } \\
\text { ates }\end{array}$ & $\begin{array}{r}\text { Sulfat } \\
\text { e }\end{array}$ & $\begin{array}{r}\text { Chlori } \\
\text { des }\end{array}$ & $\begin{array}{c}\text { Mont } \\
\mathrm{h}\end{array}$ & $\begin{array}{c}\text { Meridi } \\
\text { ans }\end{array}$ & $\begin{array}{r}\text { Display } \\
\text { circles }\end{array}$ & $\begin{array}{c}\text { Locati } \\
\text { on }\end{array}$ & \\
\hline 14.22 & 423.29 & 178.13 & 277.19 & 202.18 & 9.09 & $\begin{array}{l}760.3 \\
2 \\
\end{array}$ & 725.21 & $\begin{array}{l}\text { Septe } \\
\text { mber }\end{array}$ & 44.53 & 32.0 & $\begin{array}{r}\text { Samp1 } \\
\text { e1 } \\
\end{array}$ & \\
\hline 7.41 & 131.38 & 119.28 & 169.38 & 129.41 & 3.1 & $\begin{array}{l}554.5 \\
1 \\
\end{array}$ & 588.14 & April & 44.53 & 32.0 & $\begin{array}{c}\text { Sampl } \\
\text { e1-1 }\end{array}$ & \\
\hline 15.34 & 425.31 & 179.24 & 279.41 & 208.33 & $\begin{array}{l}10.0 \\
3 \\
\end{array}$ & $\begin{array}{l}773.2 \\
4\end{array}$ & 741.33 & $\begin{array}{l}\text { Septe } \\
\text { mber }\end{array}$ & 44.56 & 31.52 & $\begin{array}{r}\text { Sampl } \\
\text { e2 }\end{array}$ & \\
\hline 7.88 & 133.42 & 121.29 & 173.15 & 133.28 & 3.3 & $\begin{array}{l}559.1 \\
2\end{array}$ & 595.53 & April & 44.56 & 31.52 & $\begin{array}{c}\text { Samp1 } \\
\text { e2-2 }\end{array}$ & \\
\hline 16.36 & 426.18 & 182.62 & 281.17 & 211.27 & 11.4 & $\begin{array}{l}775.6 \\
2\end{array}$ & 748.61 & $\begin{array}{l}\text { Septe } \\
\text { mber }\end{array}$ & 44.58 & 31.44 & $\begin{array}{r}\text { Samp1 } \\
\text { e3 }\end{array}$ & \\
\hline 8.11 & 135.36 & 124.71 & 176.44 & 136.16 & 3.6 & $\begin{array}{r}561.3 \\
1\end{array}$ & 601.27 & April & 44.58 & 31.44 & $\begin{array}{r}\text { Samp1 } \\
\text { e3-3 }\end{array}$ & \\
\hline
\end{tabular}

Tab 5 showed that bicarbonate recorded its highest value (210.27) $\mathrm{mg} / \mathrm{l}$ in the third sample of the river. The lowest (120.40) in the first sample in January was potassium,

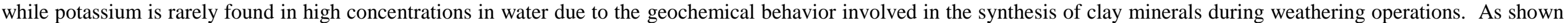

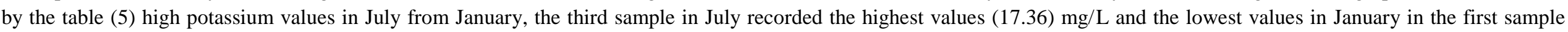

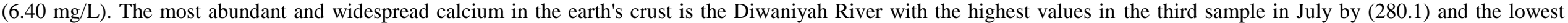
values in the first sample in January by (160.3) $\mathrm{mg} / \mathrm{L}$.

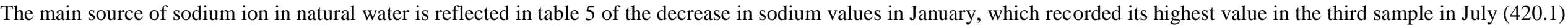
$\mathrm{mg} / \mathrm{L}$ and the lowest value in July in the first sample (130.3) $\mathrm{mg} / \mathrm{L}$ due to high temperatures and increased evaporation.

INTERNATIONAL JOURNAL OF RESEARCH IN SOCIAL SCIENCES AND HUMANITIES 


\section{THE ADEQUACY OF IRRIGATION IN THE DIWANIYAH RIVER AND ITS IMPACT ON AGRICULTURE}

To calculate the adequacy of irrigation in rivers and schedules of the study area, the following mathematical equations were applied:

1. To calculate the adequacy of irrigation, the drainage ( $\mathrm{m} 3 /$ tha) was converted for each river and schedule per day and on the days of the season (rainy or dry) divided by what the Ministry of Irrigation (currently the Ministry of Water Resources) allocated for each (4961) dunum for the dry season and 3/tha per (1144) dunum for the rainy season.

2. To calculate the deficit and flood, the adequacy of irrigation was subtracted from the area of the watering area and for the dry and rainy seasons.

The application of nasal equations $(*)$ shows that the higher the value of irrigation efficiency, the closer it is to the flood (relatively) because all the rivers and streams in the study area suffer from the deficit even though the rainy season is less than the dry season and although the region suffers from a deficit in the two seasons. According to the table (6) the adequacy of irrigation for the Diwaniyah River during the dry season was (2.60) m3, but in the rainy season it was (7.86) $\mathrm{m} 3$, and the deficit during the dry season (-347000.40) $\mathrm{m} 3$ and during the rainy season (342000.14) $\mathrm{m} 3$

\begin{tabular}{|c|c|c|c|c|c|c|c|c|}
\hline $\begin{array}{l}\text { Area of the } \\
\text { water area }\end{array}$ & Deficit & $\begin{array}{l}\text { Enough irrigation } \\
\text { for the rainy } \\
\text { season }\end{array}$ & Deficit & $\begin{array}{r}\text { Enough } \\
\text { irrigation for } \\
\text { dry season }\end{array}$ & $\begin{array}{r}\text { Discharge } \\
\mathrm{M} 3 / \mathrm{S}\end{array}$ & The name of the table or the rive & $\begin{array}{l}\text { the } \\
\text { each }\end{array}$ & \\
\hline 350000.0 & 324000.14 & 7.86 & $347000.4-$ & 2.60 & 60 & \multicolumn{2}{|c|}{ Diwaniyah River } & 1 \\
\hline 7214.0 & $7213.18-$ & 0.19 & -7213.94 & 0.06 & 1.5 & & $\mathrm{~A}$ & \\
\hline 88931.0 & $88929.76-$ & 1.24 & -88930.59 & 0.41 & 9.5 & Nuriya schedule & $\mathrm{B}$ & \\
\hline 4378.0 & $4377.95-$ & 0.05 & -4377.83 & 0.017 & 0.4 & The modern Shafi'i schedule & $\mathrm{C}$ & \\
\hline 5007.0 & $5006.72-$ & 0.275 & -5006.9 & 0.091 & 2.1 & The old Shafi'i schedule & $\mathrm{D}$ & \\
\hline 35944.0 & $35943.72-$ & 0.38 & -35943.87 & 0.125 & 2.9 & The schedule of Abbasid & $\mathrm{E}$ & \\
\hline 6241.0 & $6253.52-$ & 5.48 & -6239.19 & 1.81 & 41.8 & Sharifia schedule & $\mathrm{F}$ & \\
\hline 2285.0 & $2284.83-$ & 0.17 & -2284.94 & 0.056 & 1.3 & \begin{tabular}{|rr|r} 
Schedule of Shat $\begin{array}{r}\text { Diwaniya } \\
\text { divert }\end{array}$ \\
\end{tabular} & G & \\
\hline
\end{tabular}

\section{CONCLUSIONS}

1. Water revenue: In 2012 and 2014, the highest water revenue in all the rivers studied was the highest in 2014, with a record of 14,758,000,002 m3/year, while The years 2015, 2016 and 2017 accounted for the lowest water revenues due to fluctuating rainfall and high relative humidity, with 2015 recorded a water revenue of 9,542,880,000 m3/year.

2. Enough irrigation for the Diwaniyah River during the dry season (2.60) $\mathrm{m} 3$, but in the rainy season (7.86) $\mathrm{m} 3$, the deficit during the dry season

3. Most of the physical properties of the Diwaniyah River rise in July and decrease in January due to the low water level in the river as well as the peak of the river's zigzag activity.

\section{SOURCES}

(1) Ali Abdul Zahra Kazem al-Waili, Surface Water Resources and Its Impact on Agriculture in Al-Qadisiyah Governorate, Professor's Journal, No. 51, Faculty of Education - Ibn Rushd, University of Baghdad, 2004, p. 530.

(2) Ministry of Water Resources, Diwaniyah Water Resources Directorate, Employment Division, Unpublished Data, 2018.

(3) Ministry of Water Resources, Directorate of Water Resources in Diwaniyah, GIS Division, Unpublished Data, 2018.

(4) Ministry of Water Resources, Diwaniyah Water Resources Directorate, Employment Division, Unpublished Data, 2018

(5) Ministry of Water Resources, Diwaniyah Water Resources Directorate, GIS Division, Unpublished Data, 2018 